\title{
Marcel Monnier's Portrayal of Hawaiians in Un printemps sur le Pacifique
}

\author{
MARLA ARBACH
}

The travelogue Un printemps sur le Pacifique relates a voyage to the Hawaiian Islands undertaken in 1884 by French globetrotter Marcel Monnier (1853-1918), who would later publish accounts of his voyages to South America, Africa, and Asia. ${ }^{1}$ The 269-page book, published by Plon in 1885 , consists of sixteen chapters that cover the author's time on O'ahu and on Hawai'i Island in an approximately even split, accompanied by sixteen woodcuts by Ernest Martin-Chablis and a special map of the regions visited. Narrated in the first person, like all good travelogues, the text claims to be a true account of the author's adventures, although he also inserts some items of a different nature: two recipes, for example, and a legend (that of Kaala, the "Flower of Lanai", which he claims to have translated faithfully from an English transcription of an oral performance). A second edition of the book, published in 1888, is identical to the first edition except for a four-page note appended to the text, dated November 1887 , in which the author takes advantage of an unexpected layover in Hono-

Marla Arbach teaches French at Carleton University, Ottawa, Canada. She completed her $P h D$ in Comparative Literature at the University of Santiago de Compostela (Spain) in 2013. Her current project on Hawai'i and Hawaiians in nineteenth-century French literature developed out of her volunteer research for the 'Iolani Palace education department. Her other area of specialization is identity and diversity in twenty-first-century television series. Her research, teaching, and educational development work are fundamentally oriented around questions of diversity, privilege and Otherness.

The Hawaiian Journal of History, vol. $5^{\mathrm{o}}$ (2016) 
lulu to comment on the "progressive transformations of political and social life under the influence of the White race," ${ }^{2}$ briefly discussing the labor situation and the Bayonet Constitution and reiterating the strategic importance of Hawai'i's location at the halfway point between America and Asia. ${ }^{3}$ The book has not been reissued since 1888 and there is no evidence that it was ever translated into any other language. This article, which is part of a larger research project on Hawai'i and Hawaiians in nineteenth-century French literature, will look at the way Monnier portrays Hawaiians in his text.

In the first chapter of the book, the narrator explains how he decided to take a trip to Hawai'i: while touring California, he and his companion had often considered visiting one of the Pacific archipelagos. Stuck in San Francisco during the winter, unable to venture very far from the city due to bad weather conditions, they found themselves at the house of an unnamed friend who had recently made the trip to Hawai'i, who

would not stop talking about the incomparable vegetation of the islands, about the strangeness of the jolly and childlike population clad in flowers and foliage. And as he evokes the splendors of Polynesia, the rain beats against the windowpanes, a shrill wind howls on the streetcorners, and at our feet, on Sutter Street, passersby quicken their steps under the downpour, ducking their heads with an air of gloomy resignation. Well, then, all right, let's go to Oceania; it's so close!"4

And so they embarked on a month-long trip to the Hawaiian Islands that would take them to various locations on O'ahu, including Honolulu Harbor, Chinatown, Punchbowl Crater, Nu'uanu Pali, Waikīkī, 'Iolani Palace, Saint Louis and Punahou Schools, Waimānalo, Mauna ‘Ala, Queen Emma Summer Palace, and Ah Fong's Garden. (At least, all these locations are featured in the book; it is possible that the author and his companion did not visit them all, but rather, included hearsay descriptions of some of them.) After visiting O'ahu, they boarded the steamer Kinau, whose route took them past Moloka'i, where they stopped at the Kalawao settlement, and then past Maui, where they visited Lāhainā, Mā'alaea, and Makawao, where they trekked up Haleakalā. Their first port of call on Hawai'i Island was at Kawaihae, where the narrator describes "a curious vestige of pagan times," ${ }^{5}$ a heiau (possibly Pu'ukoholā) located nearby; they visited 
Kealakekua, then returned to Kawaihae and continued around the Kohala Coast and down the Hāmākua Coast to Hilo Bay. After visiting Hilo town and Waiānuenue Falls, they trekked to Kilauea, then returned via Waipi'o Valley and Waimea to catch the steamer back to $\mathrm{O}$ 'ahu. There, they attended the opening of the legislature and spent their final evening at the French Consulate on Beretania Street before returning to San Francisco.

The narrator never tells the reader who accompanied him on his trip to Hawai'i. However, he often uses the first person plural, indicating that he had at least one travel companion, and in chapter twelve he mentions the time his companion was almost killed when they ventured into a tide pool they mistook for a safe swimming area. Monnier's other books from the same publisher indicate that the illustrations were based on sketches and/or photographs taken by the author, so by extension, it is unlikely that the book's illustrator, Ernest Martin-Chablis, accompanied him to Hawai'i. Searching for references to Monnier's trip in the Hawaiian newspapers available online on the Chronicling America site returned three results. The Daily Bulletin reported Monnier's arrival and that of a Paul d'Arbarede on the Mariposa on April 8, 1884 and also reported their departure on the Alameda on May 1 of that year (mistakenly referring to Monnier as "Mrs. Monnier"). On May 10, the Saturday Press devoted a few lines to them under the heading "Local Items":

Marcel Monnier and Paul d'Auberacle, two young Parisian Barons, were quartered at the Hawaiian Hotel until last Tuesday, when they left on the Alameda. They had been six months in arriving thus far on their circuit of the globe. They were surprised to see the high state of civilization in Honolulu. They visited with great interest the several isles of the group, and especially the volcano, craters and lava beds. One day last week, Father Sylvester of St. Louis College went out for a ride with these gentlemen to Diamond Head and other points of interest near the city.

I have been unable to find any further information on Monnier's travel companion.

Monnier's book was received very positively in Europe by both a scholarly and a general audience and it was awarded the Montyon prize by the Académie française in 1888 . The newspaper Gil Blas praises the author's "brilliant style" and "talent in piquing readers' interest" 
in the Hawaiian people, whom it calls "curiosities by virtue of their particularly original customs that are almost unknown in France." 6 The Bibliothèque universelle et revue suisse also praises Monnier's narrative style and his ability to engage readers, concluding that "After such an appealing voyage, we close the book enchanted by its tour guide and leave dreaming of vacations and big bags of money that would allow us to go enjoy the charms of delicious Hawai 'i." " Though the French literature reviewer from the British publication Saturday Review of Politics, Literature, Science and Art does criticize Monnier for beginning the book "in that mingled key of elaborate jest and highly ornate description which too many travel-writers of all countries, and too many French travel-writers especially, are accustomed to affect," ${ }^{8}$ he concludes that overall, he is "a writer of sense and good taste" and that despite the lack of originality of the subject matter, the book "deserves to be very well spoken of."10 Reviewers continued to praise Monnier's skill as a writer years after the book's publication: speaking to its members in 1893 , before a scheduled lecture by Monnier, the Secretary General of the Société de géographie de Toulouse, Stanislas Guénot, summarized the book and offered his opinion that

in it, we find, like in all the other studies by the same author, a serene impartiality, a remarkable perspective, a conscientious search for the truth and that calm, measured tone, as removed from systematic denigration as from enthusiastic admiration, that inspires confidence. In a light and spiritual form, the author has done the job of a historian and his work is worthy of consideration by all who are interested in the great questions of human psychology, in the evolution of races and in the expansion that is necessary. ${ }^{11}$

Many of the reviews praise the book for its level of detail and factual correctness. Dr. E.-T. Hamy, director of the Revue d'ethnographie, states that "throughout his tale, Mr. Monnier has outlined the most distinct traits of contemporary Hawaiians' physiognomy and good illustrations add to the exactitude of his descriptions." ${ }^{2}$ The newspaper Le Rappel highlights Monnier's description of Hawaiian volcanoes as a point of great interest, noting that "What the author says about them would in itself be reason to seek out his book, which is also noteworthy for the details it gives of local customs." ${ }^{13}$ The book inspired a detailed response from Henri Jouan (1821-1907), a former captain in the 
French Navy, who had carved out a distinguished intellectual career by publishing scholarly works on the places and cultures visited during his naval career, including a hundred-page report on the Sandwich Islands (1873) ${ }^{14}$ In his response to Monnier's book, titled "The Hawaiian Islands and Travellers' Errors," cies that we find in his book, [which] do not detract at all from its overall value for a general audience," with the motive "that this might inspire [the author] to put out a new edition without these little blemishes that mar the first edition in the eyes of specialists." ${ }^{16}$ As we have seen above, Monnier did not correct the errors, doubtless satisfied with Jouan's overall impression of the book: he, like all the other reviewers, concludes that "this volume, full of details and facts presented most faithfully, at the same time full of humor, very easy to read, thanks to the way in which it is written, has all it needs to please the reader." ${ }^{17}$

One interesting aspect of the many positive reviews of Monnier's book is the way they retransmit the author's patronizing attitude toward the Hawaiian people with no indication that they challenged it. The Société de géographie commerciale de Bordeaux explains some of the natural phenomena and customs featured in the book: "What struck Mr. Monnier and what he describes with a great deal of charm are the natural beauty of the Hawaiian archipelago, the eternal springtime, the perpetual flowers covering the ground and the people, the virgin forest and the great craters; it is also the gentle customs of the natives, their affability, their childish indolence and simple pleasures." ${ }^{18}$ The Société de géographie de Lyon opines that the author is skilled at persuading the reader of the "irresistible charm" ${ }^{19}$ of Hawai' $i$, including the fact that "Time, for the natives, is spent singing and braiding garlands out of the flowers that bloom on all sides there. Hawaiians are a race of children who are happy with their lot; it is the sun, which always shines down generously on them, that produces this miracle." ${ }^{20}$

Although Hawaiians then and now might take pride in their cultural traditions like mele and lei, and in some of the characteristics the French ascribed to them, like their friendliness and their love of the simple life, the language used in these reviews suggests that Monnier displayed a colonial attitude toward Hawaiians and that his readers accepted without hesitation a portrait of the Hawaiian people that reinforced that attitude. Let us now turn to some examples from the text to confirm this hypothesis. 
What are the first impressions the author gives us of the Hawaiian people? Aside from the passage quoted above, in which he paraphrases his host's comments about Hawai'i and its people, he does not even mention them until the end of the second chapter, although in the first two, he discusses the history of Chinese immigration to the United States and Hawai' $i$ and expresses a fairly harsh opinion of Chinese people's character (an opinion shared by many Westerners at the time). As the Mariposa arrives in Honolulu, the narrator comments on the presence of "colorful crowds, composed of residents of European origin and of natives" and highlights in particular the "feminine element [which] dominated, in all its finery. Very simple attire: a long dress, with no waist, which in common terms we would call a chemise, of pink, white, blue, or jet black cloth, and a large straw hat adorned with flowers; around their necks, a necklace, likewise of flowers, hanging on their chest in a triple loop." ${ }^{21}$ After a detailed description of these lei, he summarizes his attitude about Hawaiian women's beauty, which we will find in many chapters of the book: "it is impossible to render the appearance and air of these figurines with skin of pale gold, not at all beautiful, of course, in the strict sense of the word, but possessing a boundless, lithe and sinuous charm."22

Later in the book, the narrator devotes a page to describing Hawaiian women's recreation at the bay where the Wailuku river feeds into the ocean: "A narrow platform reached by climbing up on the rough spots of the wet rockface is the meeting place of the intrepid lady divers. They settle in there with provisions for the day, calabashes of poi, and flowers. They rest there between dips." ${ }^{23}$ Hawaiian women are, therefore, good athletes, a fact confirmed by the narrator when he praises their abilities as equestrians. He does, however, employ a somewhat condescending tone when he introduces the subject of riding: "Hawaiians love riding: in this passion we can see some of the appreciative curiosity their ancestors felt when they saw the first specimen of a horse imported by English sailors." 24

In his description of the horsewomen, he calls them "intrepid" again and says that they ride "proudly" and that they "guide [their mounts] with a completely masculine energy." ${ }^{25}$ But in the same breath, he champions European ideals of beauty when he criticizes the women's physical appearance with some disdain: 
I will just come right out and say it. Hawaiian women, except those who are barely past childhood, are not at all pretty. Developed at a very early age, around age twelve, they have the grace and agility of young cats, a dark complexion, a bit like copper, ebony hair, long, but not very silky, brilliant white teeth, a sensual mouth, a bit big, splendid eyes. Past that age, they quickly degenerate into a stoutness that their loose-fitting clothing only exaggerates. On the other hand, their obesity does not hamper their agility and their dexterity, and I estimate that many of the most spirited riders might weigh a hundred kilograms, or nearly, not counting their clothing and their heavy garlands of flowers. ${ }^{26}$

If that is what he thought of Hawaiian women, how did he portray Hawaiian men? He does not mention them often in the text. When he describes the women's physical activity, he also describes the men's: surfing, which requires "uncommon strength and agility." ${ }^{27}$ But he shows little admiration for Hawaiian men aside from their athletic prowess. When he is trekking to Kilauea, the narrator explains his preparations thus:

in order to preserve our freedom of movement and the possibility of pressing on if necessary, we have decided not to bring a native with us. The natives are in general poorly mounted, the sworn enemies of long marches, and will never hesitate between making an effort to shake off their natural indolence or dealing with the nuisance of sleeping under the stars: very few speak or understand English; however, they will pause interminably at each hut, without a care for the time, a notion that eludes them, and will be a perpetual cause of delays. What do we need with an escort? The countryside is safe. Aside from wild dogs and jackals, there are no wild beasts hiding in the forests. And were it otherwise, without fail, the guide would disappear to take cover at the critical moment. Everyone agrees that the best thing is to count on no one but oneself and one's horse. ${ }^{28}$

The difference in genres notwithstanding, it is interesting to compare this opinion of Hawaiians to the one we find in the novel Ella Wilson by Charles de Varigny, ${ }^{29}$ one of the few longer works of French literature from the late nineteenth century to treat a Hawaiian subject in depth. In the novel, which I have discussed in another paper, ${ }^{30}$ the main character arrives from Britain to oversee his uncle's Hawai'i Island plantation with the support of "a native servant, Liho, whom he hand- 
picked from among the many natives employed on the plantation." ${ }^{31}$ Liho is characterized repeatedly as a faithful servant to his superior European master, which, we can assume, was intended to support the author's colonial worldview. But due to the dynamic between the servant, his master, and another white character (the pretender), this worldview is subtly undercut, white men's superiority is called into question, and the Hawaiian character leaves perhaps the most positive impression of all. Despite the fact that he is presented as an exceptional member of his people, he is described as knowledgeable and honorable, effective and perceptive, qualities that are completely at odds with Monnier's opinion of Hawaiian men.

We might ask ourselves where this disdainful attitude toward Hawaiians comes from, particularly since Monnier rarely mentions having had contact with any during his time visiting the islands. With few exceptions, all the people he mentions visiting are whites. He gives a favorable account of a two-day visit to John Adams Cummins' plantation at Waimānalo, but describes Cummins' hapa family in the most negative terms:

They presented us to the rest of the family and to its head, a handsome old man of eighty-four years, of Scottish origin. His mind is no longer very sharp, but he is pampered in the most touching way by his copperskinned grandchildren and great-grandchildren, and what a strange spectacle it is to see this grandfather, this white man, witnessing the inexorable and rapid degeneration of his race. ${ }^{32}$

On another occasion, he describes a visit to an unnamed hapa family and spends almost the entire three pages he devotes to the visit making fun of the husband for having multiple wives, offering this friendly piece of advice to the reader in a mocking tone: "If, by chance, you are invited to one of their houses, under no circumstances should you be overly surprised if the hard-working housewife presiding over the evening meal is not the same one who did the honors earlier that day at lunch." 33

Once, while they are trekking on Hawai'i Island, Monnier and his companion are obliged to spend the night as the guests of a Hawaiian who recently converted to Christianity. The narrator complains about the communication difficulties, because their host does not speak English, and about the traditional food he offers them. (It is not the 
only time he complains about Hawaiian food: when he gives a recipe for poi, he calls it "atrocious!" ${ }^{34} \mathrm{He}$ acknowledges the "scrupulous cleanliness" 35 of the bedroom, but evokes his host's poverty when he recounts having glimpsed him

saying his prayers with all the fervor of a neophyte. What can he have to thank God for, this naked savage, destitute, who lives off roots and rotten fish, captive, he and his brood, between the gloomy forest and the dreary ocean? His hut trembles bombarded by the wind, flattened by the downpour; the howling sea charges the rocks, ready to sweep away the shack and those inside it; spared today, perhaps tomorrow a great gust will carry it away like a dead branch. He prays, nonetheless, and with all his soul, in a naive ecstasy that probably mixes a fear of the ancient gods of the sea and fire with a confused vision of Calvary. ${ }^{36}$

Here Monnier uses one of the strategies I have found common in representations of Hawaiians in nineteenth-century French literature: an effort to discredit Hawaiians through constant references to Hawaiian traditions, such as references to Hawaiian gods, to human sacrifice, even to cannibalism, via the inescapable reference to Captain Cook in every text about Hawai'i. Only once does Monnier appear to present a Hawaiian tradition in a positive way, when he describes the practice of holding a vigil for the dying:

It seems that a particular and rarely lacking instinct alerts the savage of danger threatening one of his own.... As soon as a native is about to die, his relatives, his friends, and his friends' friends rush over, form a circle around the hut, and launch into the prayer for the dying, the Anaana, which, in their minds, must hasten the flight of the ailing soul. ${ }^{37}$

Even in a positive description, the author cannot help but use vocabulary with negative connotations (savage, instinct), which evokes superstition and discredits Hawaiian cultural traditions.

The king himself is not safe from the author's criticism. The first mention of the monarch is not openly critical, but it suggests that he might have some dubious habits: "The current sovereign, Kalākaua, is a civilized prince, educated, who speaks English well and who dresses, in public at least, in the European fashion." 38 This suggestion, that the king tolerates wearing clothing in public, but that in private he pre- 
fers to walk around naked, comes back later in the book ${ }^{39}$ and seems to have been a favorite subject of French satirists when they wrote about exotic princes. ${ }^{40}$

Here is Monnier's general opinion of the Hawaiian monarch: "His curiosity, like that of all his subjects, is always awakened: it is the same sociable nature, the same taste for friendly chatter, the need to see and be seen, a great good nature combined with a no less great love of finery and gallantry." 41 This is not a very harsh description; Kalākaua's reputation as a bon vivant was widespread, earning him the nickname "Merrie Monarch." However, Monnier devotes pages to describing the king's hobbies, while mentioning very seldom his political activities, a strategy that reinforces his attitude that the quaint little Hawaiians are just playing at government. And he uses the theme of superstition once again to ridicule the king for preferring the Royal Bungalow (Hale 'Ākala) to 'Iolani Palace:

His Majesty will not enter, for one incontrovertible reason. It is not enough to possess a gorgeous, brand spanking new palace; one must also be assured of being able to sleep in it safe from unwelcome nightmares and evil spirits. Well, the Hawaiian monarch is completely lacking in that assurance. Worse than that! He has been shown, loudly and clearly, that he can never rest, not for a single night, under that roof, on pain of imminent catastrophe. The palace is haunted, mysterious, bad in every way, steeped in murderous influences. Doesn't that sound like gloom and doom? Never mind! . . . It is futile to rebel: doubt is not allowed. The thing is certain. The sorcerers have declared it. ${ }^{42}$

On the whole, Monnier's description of the king is not as critical as some that I have studied in another paper on the representations of the Hawaiian monarchy in nineteenth-century French newspapers, ${ }^{43}$ nor are his descriptions of the Hawaiian people as harsh as his description of the natives of Guinea, about whom he had this to say:

If only the population had any attraction whatsoever. But there is nothing more disappointing than this black exoticism. They have no distinctive physiognomy. No originality, no standout characteristics in their customs or character, not even a shade of personality, of any type of industry, of development in the ordinary activities of life. No fettle, no charm, no color. ${ }^{44}$ 
Nevertheless, despite the fact that he does not criticize King Kalākaua as severely as he does the natives he encounters on his voyage to Africa, the author does not seem to make any effort whatsoever to overcome stereotypes in order to offer an impartial opinion of the monarch, and that holds true for all the descriptions of the Hawaiian people in the book.

We must conclude that by his disdainful and patronizing tone, and the way he makes an effort to attenuate any praise he gives Hawaiians through references to their superstition, Monnier does nothing but transmit stereotypes about colonized people in his descriptions of Hawaiians. Hawaiians are not to be taken seriously, because "The main concern of their existence is pleasure in all its forms; this savage is deeply convinced that he was created and brought into the world solely to eat, sleep, chat, and sing, swim in the ocean and assemble clever garlands of flowers." 45

\section{Notes}

An early version of this paper was presented (in French) at the Rocky Mountain Modern Language Association Annual Convention, Santa Fe, NM, October 8, 2015 .

${ }^{1}$ Marcel Monnier, Un printemps sur le Pacifique (Îles Hawaï) (Paris: Plon, 1885). Monnier, Des Andes au Para (Équateur, Pérou, Amazone) (Paris: Plon, 189o). Monnier, Mission Binger: France noire (Côte d'Ivoire et Soudan) (Paris: Plon, 1894). Monnier, Le tour d'Asie (Cochinchine, Annam, Tonkin) (Paris: Plon, 1899). Monnier, Le drame chinois (Juillet-Août I9oo) (Paris: Félix Alcan, 1900).

2 "les transformations progressives de la vie politique et sociale sous l'influence de la race blanche." Monnier, Printemps (1888), 272. All quotations from Printemps are from the 1885 edition unless otherwise specified and all translations are my own.

${ }^{3}$ Monnier, Printemps (1888), 274.

4 “ne tarit pas sur l'incomparable végétation des îles, sur l'étrangeté de ces populations enfantines et rieuses parées de fleurs et de feuillage. Et tandis qu'il évoque les splendeurs de la Polynésie, la pluie fouette les vitres, un vent aigu siffle aux angles des rues, et à nos pieds, dans Sutter street, les passants hâtent le pas sous l'averse, la tête basse, avec un air de résignation navrée. Eh bien, soit, partons donc pour l'Océanie; elle est si proche !" Monnier, Printemps, 18.

5 "un curieux vestige des temps barbares." Monnier, Printemps, 177.

6 "L'auteur, M. Marcel Monnier, dans un style brillant, a le talent de nous intéresser à ces populations curieuses à connaître à raison de leurs coutumes particulièrement originales et presque ignorées en France." Gil Blas, July 4, 1885 .

7 "Après un si attrayant voyage, on ferme le volume enchanté de son cicerone, et 
l'on s'en va rêvant de vacances et de gros sacs d'écus qui permettraient d'aller jouir des charmes d'Hawaï la délicieuse." Bibliothèque universelle et revue suisse 31 , no. 91-93 (July-September 1886): 442-443.

8 Saturday Review of Politics, Literature, Science and Art 6o (1885): 235.

9 Saturday Review, 236.

10 Saturday Review, 235 .

11 "on y trouve comme dans toutes les autres études du même auteur, une sereine impartialité, une hauteur de vue remarquable, une recherche consciencieuse de la vérité et ce ton calme, mesuré, aussi éloigné des dénigrements systématiques que des admirations enthousiastes qui inspire la confiance. Sous une forme légère et spirituelle, l'auteur a fait oeuvre d'historien et son livre est digne d'être médité par tous ceux qui s'intéressent aux grandes questions de psychologie humaine, à l'évolution des races et aux expansions nécessaires." Stanislas Guénot, Revue de la Société de géographie de Toulouse 12 (1893): 128.

12 "M. Monnier a esquissé au cours de son récit les traits les plus distincts de la physionomie de l'Hawaïen de nos jours, et de bonnes figures ajouent encore à l'exactitude de ses descriptions." E.T. Hamy, Revue d'ethnographie 4 (1885): 562.

13 "Ce qu'en raconte l'auteur suffirait à faire rechercher son livre, qui se recommande en outre par les détails de moeurs." Le Rappel, July $1_{5}, 188_{5}$.

${ }^{14}$ Henri Jouan, "Notes sur l'archipel hawaiien (Îles Sandwich)," Mémoires de la Société nationale des sciences naturelles de Cherbourg 17, no. 7 (1873): 5-104.

${ }^{15}$ Henri Jouan, "Les îles Hawaï et les erreurs des voyageurs," Revue scientifique 37 , no. 10 (July 1885-January 1886): 623-626.

16 'les quelques inexactitudes qu'on peut remarquer dans son livre n'ôtent rien à sa valeur générale pour le grand public, et si je prends la liberté de les relever, ce n'est pas pour la satisfaction de 'chercher la petite bête', mais avec l'idée que cela pourrait l'engager à faire disparaître d'une nouvelle édition ces petites taches qui, aux yeux des spécialistes, déparent la première." Jouan, "Erreurs," 624 .

17 "ce volume, rempli de détails et de faits exposés avec la plus grande fidélité, en même temps plein d'humour, d'une lecture des plus faciles, grâce à la manière dont il est écrit, a tout ce qu'il faut pour plaire au lecteur." Jouan, "Erreurs," 623 .

18 "Ce qui a frappé M. Marcel Monnier et ce qu'il décrit avec beaucoup de charme, ce sont les beautés naturelles de l'archipel hawaïen, le printemps éternel, l'éternelle parure de fleurs du sol et des habitants, la forêt vierge et les grands cratères; ce sont aussi les moeurs douces des indigènes, leur affabilité, leurs joies et leurs mollesses enfantines." Bulletin, Société de géographie commerciale de Bordeaux vol 8, no. 2 (1885): 689-69o.

19 Bulletin de la Société géographique de Lyon 5 (1884): 648 .

20 "Le temps, pour les indigènes, est employé à chanter et à tresser des guirlandes avec les fleurs qui là-bas s'épanouissent de tous côtés. Les Hawaïens sont un peuple d'enfants heureux de leurs destinées ; c'est le soleil, pour eux toujours prodigue de ses rayons, qui produit ce miracle." Lyon, 648 . 
21 "une foule bariolée, composée de résidents d'origine européenne et de natifs;" "l'élément féminin [qui] dominait dans ses plus beaux atours. Costume trèssimple: une robe longue, sans taille, ce qu'en termes vulgaires on nommerait une chemise, d'étoffe rose, blanche, bleue ou noir de jais, et un large chapeau de paille orné de fleurs; au cou un collier, de fleurs également, tombant en triple rang sur la poitrine." Monnier, Printemps, 33 .

22 "rien ne saurait rendre l'allure et la démarche de ces figurines au teint d'or pâle, point belles assurément dans le sens strict du mot, mais d'une grâce infinie, souple et onduleuse." Monnier, Printemps, 34 .

23 "Une étroite plateforme où l'on accède en rampant sur les rugosités de la paroi humide, est le rendez-vous des plongeuses intrépides. Elles s'y installent avec des provisions pour la journée, les calebasses de poï et des fleurs. Elles s'y reposent entre deux baignades." Monnier, Printemps, 187.

24 "Les Hawaïens adorent monter à cheval: il entre dans cette passion quelque chose de la curiosité admirative qu'éprouvèrent leurs aïeux à la vue du premier spécimen de la race chevaline importé par les navigateurs anglais." Monnier, Printemps, 61.

25 "Les femmes surtout sont intrépides, fièrement campées sur la haute selle mexicaine, non point assises à la mode européenne, mais enfourchant leurs montures, qu'elles dirigent avec une énérgie toute masculine." Monnier, Printemps, 62.

26 “Le dirai-je? Les Hawaïennes, sauf celles qui n'ont guère dépassé l'enfance, ne sont point jolies. Formées de très-bonne heure, elles ont, vers la douzième année, la grâce et la souplesse de jeunes chats, le teint mat, légèrement cuivré, des cheveux d'un noir d'ébène, longs, mais peux soyeux, les dents du plus bel émail, la bouche sensuelle, un peu grande, des yeux superbes. Passé cet âge, elles s'acheminent rapidement vers un embonpoint qu'exagère encore leur vêtement lâche. Il semble en revanche que l'obésité ne leur enlève rien de leur agilité et de leur adresse, et j'estime que plusieurs des plus fougueuses écuyères peuvent être évaluées à cent kilogrammes ou peu s'en faut, abstraction faite de la toilette et des lourdes guirlandes de fleurs." Monnier, Printemps, 62.

27 "une force et une souplesse peu communes." Monnier, Printemps, 188.

28 "afin de rester libres de nos mouvements et de forcer au besoin les étapes, nous avons renoncé à prendre avec nous un Canaque. Les indigènes sont en général médiocrement montés, ennemis des marches prolongées, et n’hésiteront jamais entre un effort pour secouer leur indolence naturelle et l'ennui de coucher à la belle étoile: bien peu parlent ou comprennent l'anglais; en revanche, ils feront des pauses interminables à chaque hutte, sans souci de l'heure, dont la notion leur échappe, et seront une cause perpétuelle de retards. Que faire d'une escorte? Le pays est sûr. À part les chiens sauvages et les chacals, les forêts ne recèlent aucun fauve. En fût-il autrement, le guide aurait infailliblement disparu pour se mettre à l'abri au moment critique. Le mieux, de l'avis de tous, est de ne compter que sur soi-même et sur son cheval." Monnier, Printemps, 197-198. 
${ }^{29}$ Charles de Varigny, Ella Wilson, Parley Pratt, Kiana (Paris: Plon, 1878).

${ }^{30}$ Marla Arbach, "Le mérite du héros colonial dans Ella Wilson de Charles de Varigny." Article in progress, based on a paper presented at the Rocky Mountain MLA 2014 Convention, Boise, Idaho.

31 "un domestique kanaque, Liho, qu'il avait choisi lui-même parmi les nombreux indigènes employés aux travaux." Varigny, Ella Wilson, 20.

32 "on nous présenta au reste de la famille et à son chef, beau vieillard de quatrevingt-quatre ans, d'origine écossaise. Ses idées ne sont plus très-nettes, mais il est choyé de la façon la plus touchante par ses petits-enfants et arrière-petitsenfants de couleur cuivre, et c'est un singulier spectacle que celui de cet ancêtre, de ce blanc assistant à la dégénérescence fatale et rapide de sa race." Monnier, Printemps, 136.

33 "Si par hasard vous êtes reçu chez l'un d'eux, ne soyez point surpris outre mesure lorsque la ménagère diligente présidant le repas du soir ne sera pas celle qui vous faisait le matin les honneurs du lunch.” Monnier, Printemps, 125.

34 “atroce!" Monnier, Printemps, 234.

35 “propreté scrupuleuse." Monnier, Printemps, 219.

36 "récitant ses prières avec toute la ferveur d'un néophyte ... De quoi peut-il remercier le ciel, ce sauvage nu, misérable, qui vit de racines et de poisson gâté, captif, lui et sa nichée, entre la forêt sombre et le morne Océan? Sa case tressaille assaillie par le vent, écrasée par la trombe; la mer hurlante monte à l'assaut des roches, prête à balayer la bicoque et ceux qu'elle renferme; épargnée aujourd'hui, demain peut-être un grand souffle l'emportera comme une branche morte. Il prie pourtant, et de toute son âme, naïve extase où probablement la crainte des antiques divinités de la mer et du feu se mêle à la vision confuse du Calvaire." Monnier, Printemps, 220.

37 "Il semble qu'un instinct particulier et rarement en défaut avertisse le sauvage du péril qui menace l'un des siens...Dès qu'un indigène est près de trépasser, ses parents, ses amis et les amis de ses amis accourent, font un cercle autour de la cabane, et entonnent la prière des agonisants, l'Anaana qui doit, dans leur pensée, hâter l'essor de l'âme souffrante." Monnier, Printemps, 190.

38 "Le souverain actuel, Kalakaua, est un prince civilisé, instruit, parlant bien l'anglais et s'habillant, en public du moins, à l'européenne." Monnier, Printemps, $5^{\circ}$.

39 Monnier, Printemps, 107.

${ }^{40}$ Marla Arbach, "Avis aux amateurs de pittoresque: représentations de la monarchie hawaïenne dans les journaux français du XIXe siècle.” Article in progress, based on a paper presented at the 2015 APFUCC Convention, Ottawa, Ontario, Canada.

${ }^{41}$ Monnier, Printemps, 83.

42 “Sa Majesté ne rentrera pas, pour une raison péremptoire. Ce n'est pas le tout de posséder un beau palais battant neuf, encore faut-il être assuré de pouvoir y dormir à l'abri de cauchemars fâcheux et de malins esprits. Eh bien, cette assurance fait complètement défaut au monarque hawaïen. Que dis-je! Il lui 
a été démontré de façon claire et précise qu'il ne pourrait reposer, fût-ce une nuit, sous ce toit, sous peine de catastrophe imminente. Ce palais est hanté, mystérieux, mauvais à tout égard, impregné d'influences meurtrières. N'est-ce pas jouer de malheur? Mais quoi! .. . Inutile de s'insurger: le doute n'est pas permis. La chose est sûre. Les sorciers l'ont affirmé.” Monnier, Printemps, go.

43 Marla Arbach. "Avis."

44 "Si encore la population présentait un attrait quelconque. Mais rien de décevant comme cet exotisme noir. Il manque de physionomie distinctive. Nulle originalité, aucun trait saillant de moeurs ou de caractère, pas l'ombre de personnalité, d'industrie quelconque, de recherche ingénieuse dans les occupations ordinaires de la vie. Ni forme, ni grâce, ni couleur." Monnier, France noire, 132.

45 "La grande affaire de l'existence, c'est le plaisir sous toutes ses formes; ce sauvage est intimement persuadé qu'il a été créé et mis au monde uniquement pour manger, dormir, bavarder et chanter, prendre ses ébats dans la mer et combiner d'ingénieuses parures de fleurs." Monnier, Printemps, $5^{6}$. 
